\title{
The Impact of Mortgage Loans on the Financialization Process in Turkey
}

\section{Ipotekli Konut Kredilerinin Türkiye’de Finansallaşmaya Etkisi}

\author{
(D) Ahmet Suvar Aslan, (1) İclal Dinçer \\ Department of Urban and Regional Planning, Yildiz Technical University, Istanbul, Turkey
}

\begin{abstract}
The importance of the economy created by the construction sector and the related sectors that support it has become more significant since the growth in the use of financial instruments. The influence of financial institutions has reached an unprecedented level in the shaping of the urban space with the implementation and acceleration of financialization. Geography and urban planning specialists have been at the center of the debate over financing in the United States as a result of the economic crisis that began in 2007. After the collapse of derivative markets due to the mortgage market, which was the principal cause of the crisis, the mortgage system and the urban space began to come to the forefront of financialization studies. These studies seem to be concentrated on the early capitalist countries. However, there is also a financialization process occurring in late capitalist countries such as Turkey, and this process can be observed in urban spaces. The present study aims to contribute to the financialization debates from this point of view, by evaluating neoliberal reforms, public policy, and housing market developments that were implemented in Turkey after the $200 \mathrm{I}$ economic crisis. A mixed method of analysis was applied, as it offered options a single method cannot provide. This study first describes the problem, and then the methodology is explained. A brief discussion of the concept of financialization is presented, focusing on the urban space and mortgage loans. A literature review provides an analytical basis for assessing how the housing sector in Turkey is affected by the process of financialization, and the case of Istanbul, called the financial capital of Turkey, is examined. In a late capitalist country such as Turkey, where the mortgage market volume is quite new and thus not at a level that the sector desires, the possibility that the rapidly increasing amount of household debt will cause a new economic crisis should be investigated.
\end{abstract}

Keywords: Financialization; mortgage loans; housing policy.

\section{ÖZ}

İnşaat sektörü ve onu besleyen diğer sektörlerin oluşturduğu ekonominin önemi bu sektörlerin finansal araçlarla ilişkilerinin gelişmesi sonrasında daha da artmıştır. Finansallaşma sürecinin başlaması ve hızlanması ile kentsel mekanın şekillenmesinde finans kurumlarının etkileri daha önce olmadığı seviyelere gelmiştir. Finansallaşma tartışmalarının coğrafya ve şehir planlama uzmanlarının odağına girmesi Amerika Birleşik Devletleri'nde 2007'de başlayan ekonomik kriz ile oldu. Bu krizin çıkış sebebi olan mortgage pazarına bağlı türev piyasaların çökmesi sonrasında mortgage sistemi ve kent mekanı finansallaşma çalışmalarında öne çıkmaya başlamıştır. Bu çalışmaların erken kapitalistleşmiş ülkelerde yoğunlaşmış olduğu görülmektedir. Buna karşın Türkiye gibi geç kapitalistleşen ülkelerde de finansallaşma süreci yaşanmaktadır ve bu süreci kentsel mekanda gözlemleyebilmek mümkündür. Bu bağlamda çalışma finansallaşma tartışmalarına 200 I ekonomik krizi sonrası Türkiye'sinde yaşanan neoliberal reformlara, kamu politikası ve konut piyasasındaki gelişmeler üzerinden bakarak katkıda bulunmayı amaçlamaktadır. Çalışmada tek bir yöntemin sağlayamayacağı başka seçenekler sunması sebebiyle karma yöntem belirlenmiştir. İlk basamakta ipotekli krediler başta olmak üzere kredi sistemine ilişkin veriler topland. Daha sonra ise bu verilerin yol göstericiliğinde niteliksel görüşmeler yapılandırılarak derinlemesine mülakatlar gerçekleştirildi. Çalışma ilk aşamada sorunu ortaya koymakta, daha sonra metodolojiyi anlatmaktadır. Sonrasında ise kent mekanını ipotekli konut kredilerini odağa alarak finansallaşma kavramı hakkında kısa bir tartışma sunulmaktadır. Aktarılan literatür incelemesi Türkiye'nin yaşadığı finansallaşma deneyiminde konutun hangi yönlerden etkilendiğini tespit edebilmek için analitik bir temel sağlamayı amaçlıyor ve konu, geç kapitalistleşen ülke Türkiye'nin finansal başkenti olarak adlandırılan en büyük metropolü İstanbul örneğinde inceleniyor. İpotekli konut kredisi sistemi olkuça yeni olan ve dolayısıyla sistemin hacmi sektörün istediği düzeyde olmayan Türkiye gibi geç kapitalistleşen bir ülkede hızla artan hanehalkı borçluluğunun yeni bir ekonomik krize sebep olup olmayacağı da araştırılmayı beklemektedir.

Anahtar sözcükler: Finansallaşma; ipotekli konut kredileri; konut politikası.
Received: 24.12.2017 Accepted: 13.05.2018

Available Online Date: 01.08.2018

Correspondence: Ahmet Suvar Aslan.

e-mail: ahmetsuvaraslan@gmail.com 


\section{Introduction}

The importance of the economy created by the construction sector and the related sectors that nurture it has become more significant after the development of the relationship of these sectors with financial instruments. By acting together with the sector during and after every stage of construction, financial institutions have a complex relationship with the bonds in the processes of purchasing the land, completion of construction, sale and resale of the mortgage loans in derivative markets by means of the generated financial instruments, and other. In this context, the influence of financial institutions has reached an unprecedented level in the shaping of urban space with the beginning and the acceleration of the financialization process. From this point of view, the main question of this study is explaining the spatial transformations that took place in the post-2000 period in Turkey within the framework of "financialization". The study aims to contribute to the financialization debates by taking in consideration the neoliberal reforms, the public policy and the housing market developments that occured in Turkey after the $200 \mathrm{l}$ economic crisis.

There is growing literature on financialization which has been contributed by geographers and planners who are working on the housing problem, as well as by economists. While trying to understand and interpret the early capitalized countries and the late capitalized countries like Turkey, the approaches contributing to this literature show the similarities and the differences between these two different levels of development in their narratives. The financialization process of Turkey departed from early capitalized countries due to the the fragility of the Turkish economy by reason of external dependence, excess illegal/unlicensed housing rates in the metropolises, especially in Istanbul, and the existing structural difficulties of the finance sector.

The growing liquidity pool presented as the main driving force of the housing finance (Fernandez and Aalbers, 2016) differs in early capitalized countries and late capitalized countries (Pereria 2017). The number, volume and types of loans used in the early capitalized countries and those used in the late capitalist countries such as Turkey, are not on similar levels, as well as the size of the financialization and the financial literacy.' As it will be seen later in the case of Turkey, the high level of the annual interest rate of the mortgage loans directly affects the periods of the credits used. The annual interest rates of the mortgage loans used in Turkey are higher than the similar interest rates in countries such as Holland. This constitutes a main structural problem for Turkey's mortgage markets in showing similar performance as compared to the developed countries.

The next chapter describes the methodology of the study followed by a brief discussion of the concept of financialization. The article then proceeds by summarizing the specific effect of financialization on housing. The presented literature review aims to provide an analytical basis for assessing how the housing sector in Turkey is affected by the financialization process, and this topic is examined in the case of Istanbul, called the financial capital and the biggest metropolis in Turkey.

\section{Methodology}

This study is based on the doctoral dissertation titled "Evaluation of the Financialization in Turkey Through the Mortgage Loans: The Case of Istanbul". This study uses a mixed method of both quantitative and qualitative analysis being evaluated together. The data were collected from national and international institutions. The national institutions include the Central Bank of the Republic of Turkey, the Banks Association of Turkey, the Banking Regulation and Supervision Agency, the Turkish Statistical Institute, and the five largest banks of the mortgage market by the 2014. First, publicly available data obtained from these five banks were used, and in the second phase, analysis was carried out on the information of banks providing data in Istanbul. The share of mortgage loans in the total housing sales in Turkey and Istanbul, the average amount, periods and the historical credit interest rates of these loans, the ratio of mortgage loans and the total debts of households to GNP are covered in this paper owing to the data collected from national institutions. The detailed data obtained for Istanbul include the district where each individual uses the mortgage loan, the amount of the loan, the credit period, and the demographic and employment status of the borrower. Furthermore, publicly available data are obtained from the international institutions such as the Euopean Mortgage Federation (EMF), the Bank for International Settlements (BIS), and the International Monetary Foundation (IMF).

In the in-depth interviews conducted with the experts, the main axis is focused on the general problems, potentials, market reliability, and the future of the derivative markets in Turkey in the light of findings obtained from the first stage of the study. Among the interviewed experts are four international banks, ${ }^{2}$ one of which is a public bank, four real estate investment companies ${ }^{3}$ (REICs), one of which is Emlak Konut Real Estate Investment Company, four academics and researchers, two real estate developers, ${ }^{4}$ two real estate

\footnotetext{
According to TEB, which gives financial literacy education and publishes the financial literacy access index, financial literacy is "the level of competence that enables the consumer to make informed evaluations in the use and management of money and to make effective and rational decisions in the selection of financial instruments."

2 Mid-level managers of Ziraat Bankası, Yapı ve Kredi Bankası, İş Bankası and iNG Bankası were interviewed.

3 A mid-level manager of Emlak Konut REIT, a senior manager of iş REIT, a senior manager of Nurol REIT and a mid-level manager of Tekfen REIT were interviewed.

4 A senior manager of the Strategy Platform for Real Estate and a senior manager of Cushman \& Wakefield were interviewed.
} 
appraisers, ${ }^{5}$ two Mass Housing Administration officials, ${ }^{6}$ an international real estate company operating across the country, ${ }^{7}$ and a media company ${ }^{8}$ from the real estate sector.

According to the Turkish Statistical Institute's (TUIK) data, it is seen that the city where the mortgage loans are used the most in Turkey from 2009 until the end of 2016 is Istanbul with 624.034 , followed by Ankara with 364.547. In this period, the mortgage loans used in Istanbul increased by 926.9\%. Istanbul is $41.12 \%$ higher than Ankara in the hedonic price index of the Central Bank of Turkey for December 2016. When considering the ratio of mortgage loans used in Turkey by 2016, to the population of each province in 2016 , Ankara comes first with a mortgage loan of 14.66 people. Istanbul is the $8^{\text {th }}$ among all provinces with a mortgage loan of 23.64 people. When all these data are evaluated together, the significant role of Istanbul cannot be denied in terms of mortgage loans and the construction sector. Therefore, a study that aims to explain the spatial transformation in Turkey through financialization should examine the city of Istanbul in the first place.

\section{Conceptualizing Financialization}

At the present time, debates of housing problem focusing on mortgage loans can not avoid the conceptualization of the financialization. This situation raises different theoretical debates on the concept of financialization, but also causes blurring of the concept. This sub-section focuses primarily on the literature that evaluates the financialization debate through the mortgage loans.

"In the literature, there are various explanations for the rise of financialized capitalism. Many financialization scholars situate the beginning of financialization in the 1970s with the industrial crisis in the West, the breakdown of the Bretton Woods system, and the rise of neoliberalism... More generally speaking, financialization is part of and key to structural transformations of advanced capitalist economies. We here define financialization as "the increasing dominance of financial actors, markets, practices, measurements and narratives, at various scales, resulting in a structural transformation of economies, firms (including financial institutions), states and households" (Aalbers, 2016)."

Along with the economic crisis that began in the United States in 2007, geography and city planning experts have focused on the debate on financialization. After the collapse of the derivative markets due to the mortgage market, which was the outcome of the economic crisis, the mortgage system and the urban space began to come to the forefront of the financialization studies. These studies seem to be concentrated on the early capitalist countries (Aalbers, 2017). However, there is also a financialization process in the late capitalist countries such as Turkey, and this process can be observed in urban spaces.

One of the frequently mentioned statements when defining financialization is the one made by Krippner (2005). Following Arrighi's (1994) study, she defines financialization as "a pattern of accumulation in which profits accrue primarily through financial channels, rather than through trade and commodity production"'.

The definition of Krippner offers a broad context for financialization, including housing. In this context, we aim to discuss the role of space in financialization. The capital tries to remove the spatial obstacles to facilitate its circulation. This contradiction between movable capital and immovable properties lies at the bottom of modern capitalist urbanization. As a result of this tendency inwhich the liquidity of capital comes to the fore, the power of finance capital is increasing (Gotham 2009). The flow of the capital to the secondary circuit is one of the determining factors of this process. As Harvey (1985) has pointed out, "urbanism has consequently been transformed from an expression of the production needs of the industrialist to an expression of the controlled power of finance capital, backed by the power of the state, over the totality of the production process." As revealed by Harvey in 1985, this point is an important basis for the role of the state in the financialization debates focusing on housing.

Once Gotham identifies the financialization in a broader sense, he draws attention to the critical point of its relation with real estate. According to Gotham (2009), "as a multidimensional, contested and conflictual process; financialization refers to the growth of financial actors (banks, lenders, private equity corporations, etc.), new financial tools (mutual funds, asset-backed securities, hedge funds, etc.), and the increasing significance of financial firms in different areas of the economy such as real estate" In this sense, securitization is a critical component of the financialization process (Aalbers, 2009, Newman, 2009, quoted in Gotham 2009).

The financial sector has played an important role in the accumulation and circulation of the capital throughout the history of capitalism. With the period following the collapse of the Bretton Woods system, it is observed that the role of

\footnotetext{
5 Senior managers of Vakıf Real Estate Apprasial Inc. and Istanbul Real Estate Valuation and Consulting Inc. were interviewed.

6 Two senior managers of the Housing Development Administration of Turkey were interviewed.

7 A mid-level manager of ReMax was interviewed.

8 The editor of Journal of Gayrimenkul Türkiye was interviewed.
} 
finance in capitalist economies is increasing and deepening. As discussed frequently in the literature on finance, there has been a series of transformations in the financial field in many countries, especially in central capitalist countries. Progresses such as the development of a new style of governance based on the shareholder value of the companies, the increase in derivative instruments and securitization, the diminishing role of financial intermediaries, and the increasing frequency of financial crises were among the most striking elements of this process (Karaçimen 2015). Intertwining with traditional methods, modern financial markets have offered more risk management opportunities for companies, and created a multitude of channels through which volatility in the financial system can flow. Assets that change hands in the financial arena symbolize future income. The capitalization of income to be earned in the future provides for the formation of capital that does not exist yet, but it is traded so. This is the abstraction of the production field. Another important development observed during this period was that finance took an unparalleled place in the lives of individuals. One of the most obvious indicators of this case is the tremendous increase in household loans in many countries, including Turkey (Akçay and Güngen, 2016).

Fainstein (2016), argues that the recent intensification of financialization alone has not produced an uneven development. According to her, financialization is intrinsic to the neoliberal ideology and globalization. Hence, an inequality arises which is generated by the investment of real estate, and state-sponsored social welfare and housing affordablility programs are being narrowed. Fainstein has relatively more positive opinion on financialization. According to her, the coexistence of flexibility provided by the financialization and the new construction and renovation techniques can provide better distribution of the benefits of urban development. The politics that prevent the access of this potential is the austerity policy. Fainstein mentions the democratizing aspect of financialization. However, the "democratization" of financialization has manifested itself as the spread of debt to all segments of the society, and has resulted in the increased debt of the narrow-income households.

According to Fields (2015), financial markets and actors are becoming increasingly centralized in the functioning of capitalism and redrawing the relationship between the use of mortgage loans and urban inequality. The hegemonic role of finance in neoliberal restructuring constitutes a major debate on the practices of contemporary communities. Market liberalization policies, such as deregulating the banking and financial industries, and opening up global capital flows, have ensured that financial markets and actors have a more direct influence on the production of urban space (Gotham, 2009).

\section{Financialization of the Construction Sector in Turkey}

The debate on financialization is mainly shaped by the developments in the early capitalist countries However, these developments also affect the markets in the late capitalist countries such as Turkey, which has been included in the global system, and financialization is seen in these countries as well. Studies in the financialization literature usually include early capitalistized countries (eg Dymski 2009, Gotham 2009, Haiven 2014, Durand 2017, Loon and Aalbers 2017, Aalbers 2017). It is also possible to say that there is a growing literature on the financial experience of late capitalist countries (eg Rolnik 2013, Yalman, Topal and Steel 2016, Güngen 2017, Pereria 2017). An official strategy aimed at involving more people in the financial system and making it easier for them to access the financial services in Turkey was announced with the publication of "Financial Access, Financial Education, Financial Consumer Protection Strategy and Action Plans", which was published in 2014. Furthermore, the legal sub-structure of the securitization has been prepared in accordance with the "Communiqué on Principles Regarding Mortgage Finance Institutions" issued in 2014. This strategy has been shaped in line with the policy of spreading the financial services to the grassroots level that is determined by G20 principles. The objective of the strategy document published in the official gazette is given below:

"The main purpose of the strategy is to spread the financial products and services to all segments, to include offsystem outsiders into the financial system, and to increase the quality and use of existing products and services. In this framework, the strategy aims to increase the access and use of financial products and services through increased knowledge and awareness. It is also aimed at taking effective measures to protect the financial consumer led by the relevant actors."

It is hoped that every segment of society will use financial products and each individual will benefit from the democratization of finance by making rational decisions. As it can be seen in the next section, the result is an unavoidable increase of household debts. Before these action plans, traces of the financialization in Turkey have become apparent since 200I, when the biggest economic crisis of the country arose.

The global liquidity abundance, which emerged under the influence of policy responses in the early capitalist countries in the period following the 2008 crisis, had an effect on the high economic growth rates recorded in many late capitalist countries, including Turkey. Derivatives markets that are de-

9 http://www.tcmb.gov.tr/wps/wcm/connect/feb004f0-bb3c-4d52-bbff-086c0c72c072/eylemplani.pdf?MOD=AJPERES\&CACHEID=ROOTWORKSPACE-feb004f0-bb3c4d52-bbff-086c0c72c072-kCzrKGg 
pendent on housing financing are not sufficiently developed in late-capitalist countries. Secondary markets in Turkey are not as advanced as those in the early capitalist countries. Even if these markets were to be developed by the state and capital owners, the economic crisis that started in 2007 led to a cautious treatment of this issue. Nevertheless, the real estate certificate system, which is a derivative system, has entered into force. While low interest rates in Turkey have encouraged growth in the housing sector, consumer loans and use of credit cards have been instrumental for low-wage society segments in increasingly benefiting from mainstream financial services. Turkey is similar to other late capitalist countries; however, financialization and the inclusive financing process proceed different from other countries due to the proactive role of the government and the effectiveness of the representatives of the financial sector (Güngen, 2017).

The economic crisis that started in Turkey in 2001 was the biggest crisis in the history of the country. In order to overcome this crisis, new institutions were established or new structuring took place providing the power transfer between existing institutions (Akçay, 2009) such as the Banking Regulation and Supervision Agency (BRSA) and the Energy Market Regulatory Authority. The fact that the Central Bank was left to technocrats by gaining autonomy and the BRSA was given extensive authority for the banking sector, were the important reforms aimed at overcoming this crisis (İslamoğlu, 2002). The central government carried out these practices, which surpassed the previous neoliberal programs with the help of the IMF. The ruling Justice and Development Party (AKP), which came into power as a single party in 2002, continued this program and implemented privatization practices of an unprecedented size in the history of the country. When this program was followed, policies and developments in the construction sector played an important role in overcoming the crisis. By making 198 new legislative arrangements in the field of built environment production after 2002, the state has performed interventions encouraging the production of urban built environment (Penpecioğlu, 2016). Between 2002 and 2007, the GDP grew by an annual average of $7 \%$, while the construction sector grew by an annual average of $11.6 \%$ (Çelik and Karacimen, 2017). When the construction sector and the related sectors that feed each other are examined together by taking the same network with the construction sector, the percentage of the construction sector in GDP reaches a $20-25 \%$ level (Dinçel, 2015). A similar picture of the growth in the construction sector in Turkey between 1982 and 1987 was also seen after 2002. This explosion in the housing sector was a combination of policy responses against the economic crisis after 200I, and the desire of new elites of the state to ensure that Istanbul enters into the global cities network. This rapid growth in the construction sec- tor was achieved through several channels. Thus, the central government incorporated all the authorisation concerning urban planning and structuring by continuous revisions on preparation and regulations of spatial plans via the Ministry of Environment and Urban Planning. Another important change is that the reconstructed Housing Development Administration (TOKI) gained planning authority to increase its ability to invest, as well as the rapid expansion of its financial resources. By means of legal regulations the Housing Development Administration (TOKI) obtained the ability to act as an economic enterprise in the construction and real estate sector (Penpecioglu, 2016). The government, which regulates the access to the financial market and the borrowing system, provides information to the financial market to enable the capital to survive, and thus, acts as an actor that is embedded in the capital but is also autonomous. Aside from being embedded in the capital, it is present as capital as well as by means of TOKI. Thereby, it also undertakes a task other than being a regulator among the classes that produce and consume the housing (Ergüder, 2017).

\section{General Structure of the Mortgage Loans in Turkey}

This study attempts to understand the structure of the mortgage loans in Turkey, in order to understand the financialization debates through the case of Turkey as a late capitalized country. It is aimed at understanding the relationship between mortgage loans and the financialization process by trying to explain the effects of the scale and volume of mortgage loans, the loan to value (LTV) rate, taken in consideration while lending loans, and the share of income in repayment on the mortgage loans used in İstanbul and in Turkey. For this purpose, as mentioned in the introduction, data were gathered from different institutions at different stages of the study, and in-depth interviews with experts were conducted.

In the chapter titled "Sustainable And Inclusive Urban Prosperity And Opportunities For All" of the Habitat III New Urban Agenda, it is committed that sustainable and affordable housing and housing finance will be supported at national, sub-national, and local levels. Furthermore, in the fifth chapter of Turkey's National Report on Habitat III, affordable housing finance is discussed under the sub-title of "Improving and Strengthening Access to Housing Finance". In this study, it is argued that the housing investments have grown through the rapidly increasing mortgage loan possibilities after 2002. Turkey argues that urban wealth will be distributed more equitably to citizens by means of mortgage loans.

The Law on Amendments to Various Laws on the Housing Finance System No. $5582^{10}$ also introduced regulations on

\footnotetext{
10 The Law on Amendments to Various Laws on Housing Finance System No. 5582 was approved on 2 Ist Februrary, 2007.
} 
credit use. One of the prominent items in the regulations for the use of the mortgage loans is the fact the a lender can only give credit after the assessment of buildings by real estate companies licensed by the capital market institution. Another important point is the Itv rate. In 2007, when the mortgage law became legal, the Itv rate was set at $75 \%$. This percentage was raised to $80 \%$ in the last quarter of 2016 . The Itv rate is a major obstacle for people without a certain capital accumulation to be able to buy dwellings using mortgage loans. From the enforcement of the law to the last quarter of 2016 , individuals who wanted to buy a home using a mortgage loan had to have $25 \%$ of the housing price they intended to buy. In the last quarter of 2016 , this rate was reduced to $20 \%$. In other words, the necessity of people having a certain capital accumulation in order to buy a home was presented as a prerequisite by law. The possible consequences of preventing access of classes, which could not make capital accumulation, to mortgage loans were among the questions asked to the experts in the in-depth interviews conducted under this study. To summarize the answers given; all of the interviewed bank managers state that the LTV ratio is an important tool in terms of preventing the system from having a financial crisis. The interviewees indicate that by using this tool people with poor credit scores, who are likely to make a payment with difficulty, are prevented from getting a mortgage loan, and so, it is ensured that mortgage loans under administrative follow-up rates are very low. In fact, all other interviewees agree on this issue, only one of the real estate developers said that the banks pursue a very conservative policy by using a high percentage of Itv ratio, thus causing a transformation of the market that brings it below the desired level. In examining the data of the Banking Regulation and Supervision Agency (BRSA), it can also be seen that by July 2017 , the ratio of the total sum of mortgage loans under the administrative followup to the volume of mortgage loans is $0.46 \%$, which is a lower rate of non-performing loans. In the same interviews, it is indicated that another reason for this low rate is that homes are not perceived just as an investment tool in the Turkish society, rather they are seen as one of the binding agents holding the family together. Thus, other expenses can be reduced in order not to lose the home, and if necessary, mortgage loans are paid with the help of the extended family members. Thereby, it is emphasized that the mortgage back payment rates are much higher than the other personal loan rates.

It is above all obligatory that the residential building for which the mortgage loan will be used has a building use permit. It is known that the vast majority of housing stocks in Turkey and Istanbul do not have this permit (Balaban, 2007). In the study of Kömürlü and Önel in 2007 , it is said that roughly $55 \%$ of all the homes in Turkey are unauthorized. Moreover, according to the statement made by the Istanbul Metropolitan Municipality Mayor Kadir Topbaş" in 2008, most of the buildings of I million 194 thousand 643 in Istanbul are incompatible and illegal structures, and $57 \%$ of these buildings are unlicensed and are not meeting legal and technical procedures. This also shows the great difference between the domain of the mortgage loan market in the early capitalist countries and the theoretical domain of the market in Turkey. The mortgage market in Turkey cannot appeal to the entire housing market.

Mortgage loans which began to be used in Turkey in 2007, became an important alternative for housing ownership in a short span of time. While $34 \%$ of the residential sales made in Turkey in 2016 by using mortgage loans, this rate was $38 \%$ for residential purchases made in Istanbul for the same year. While the period of mortgage loans used in 2016 was 90 months (7.5 years), borrowers used mortgage loans for an average amount of $\$ 36.500$ in the same period. Creted according to the data obtained from the Central Bank of the Republic of Turkey, figure I shows the average annual interest rates of mortgage loans borrowed from the banks since 2007. In November 2008, the average annual interest rate reached its highest level with 22.69\%, and in December 2016 it reached $11.43 \%$ with a fluctuating process. The fact that the loan interest rates are considerably higher than those of the early capitalized countries ${ }^{12}$ constitutes a structural obstacle to the progress of the credit period spreads to 20-25 years. The interviewed bankers and real estate developers also see this as another factor that poses an obstacle for opening up mortgage loans to the access of low classes.

The importance of the measures taken after the 200I crisis

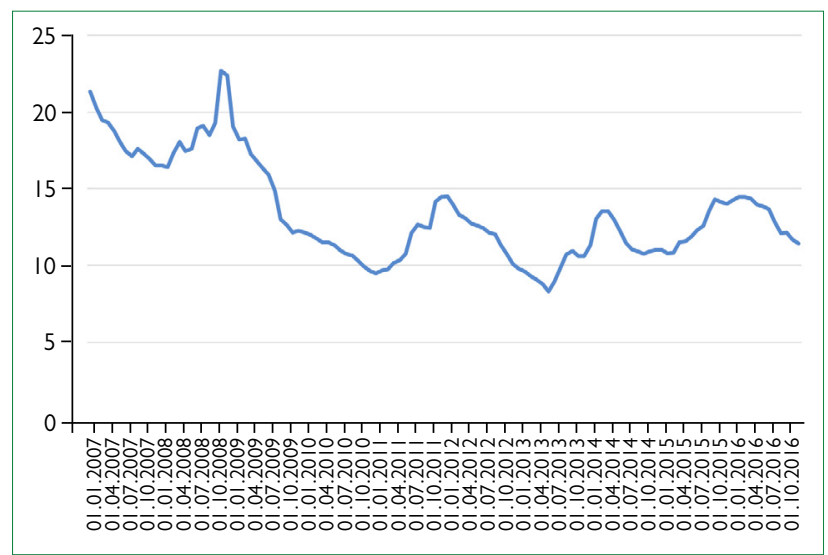

Figure I. Average Interest Rates of Mortgage Loans between 2007-20 I6. Source: The Central Bank of the Republic of Turkey.

\footnotetext{
11 http://www.hurriyet.com.tr/topbas-deprem-konusunda-yitirecek-I-dakikamiz-yok-9683293

${ }^{12}$ At this point, numerical data on the average interest rates of mortgage loans will be useful to understand the gap between in some of the early capitalized countries and in Turkey. The annual interest rate of the mortgage loans is $2.59 \%$ in Holland, $2.34 \%$ in UK, 3.65\% in USA, $2.01 \%$ in Spain and $1.06 \%$ in Japan (EMF, HYPOSTAT 2017 A Review of Europe's Mortgage and Housing Market)
} 
for the financial process in Turkey was mentioned above. In figure 2, the ratio of the residential loans to GDP between 2002 and 2016 is shown by using data obtained from the EMF. Figure 3, visualized using the EMF data, shows that the volume of the residential loan sector in Turkey has a continuously increasing structure over the years. The households' GDP rated residential loan debt has a general upward trend, although it has declined for some years. Figure 4, generated from the data published by the BIS, shows the ratio of the total household debt to GDP in Turkey. There are some similarities between figure 2 and figure 4 . Both charts show a slight decrease in the debt-to-GDP ratio after 20I3. On the contrary, the total residential loan debt of the household indicated in figure 3 increases exponentially. This is in line with the arguments of some bankers, real estate developers, and interviewed academics, who stated that the mortgage market in Turkey is expanding and has a potential for more expansion. The increasing household debt is one of the indicators of the financial inclusion process. It is also necessary to mention that all those who can use mortgage loans in Turkey belong to the middle or the upper classes. The sector constituents interviewed mention that these people are the ones who are

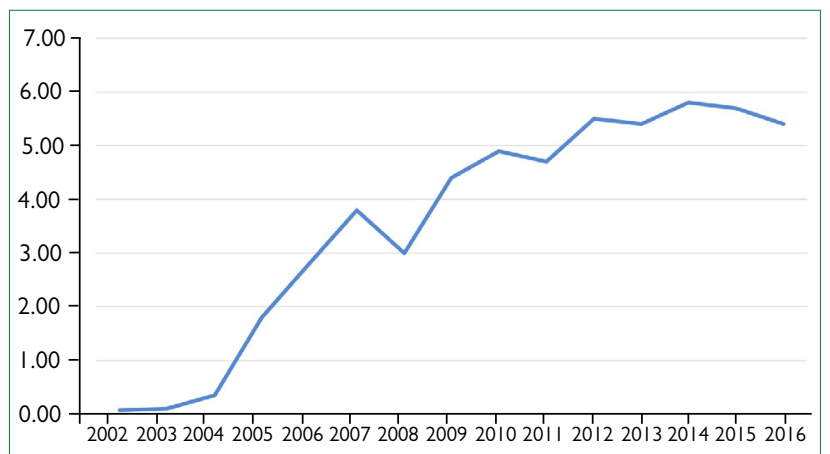

Figure 2. The households' ratio of total credit dept to GDP in Turkey. Source : EMF, HYPOSTAT 2017 a review of Europe's mortgage and housing market.

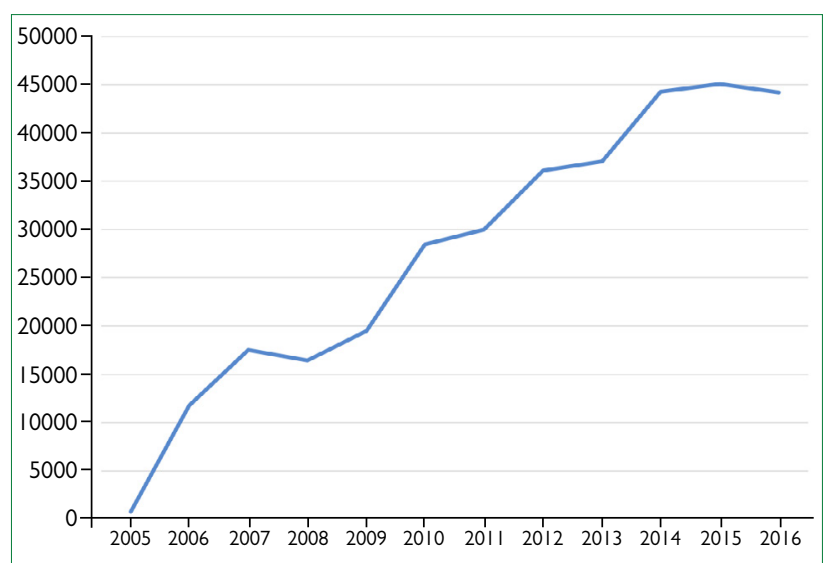

Figure 3. Total mortgage loan debt in Turkey between 2005-20l7 (million euros).

Source: EMF, HYPOSTAT 2017 a review of Europe's mortgage and housing market more literate in financial terms, and were involved the financial inclusion process before the mortgage loan process.

When looking at the data for Turkey, it is not wrong to say that the financialization has been increasingly taking place in parallel with the post-2002 period. Both the data obtained and the enacted laws such as the issuance of mortgage laws or the promulgated documents including the Financial Access, Financial Education, Financial Consumer Protection Strategy and Action Plans, which was published in 2014 as mentioned earlier, support this view. Choosing the countries according to the focus of the study, figure 5 shows the ratio of the total household debt to GDP in some of the early capitalized countries and in the late capitalized countries such as Brazil and Turkey using the data obtained from the BIS. Turkey's household debt has increased more than triplicate in I I years. A similar trend applies to Brazil. The financialization process of these countries continues rapidly.

\section{Spatialization of the Mortgage Loans in Istanbul}

According to the data of the Turkish Statistical Institute for 2015 , Istanbul is the most populated city in Turkey. Its population is 14.657.434 habitants, and it has the highest popula-

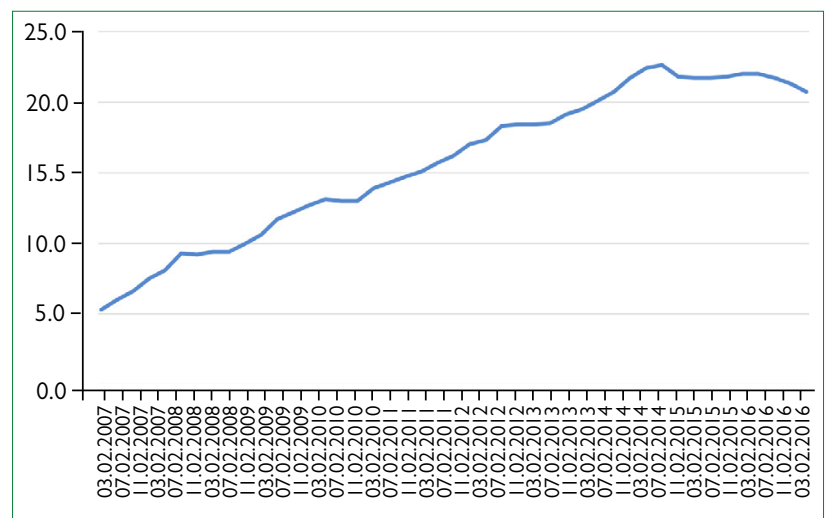

Figure 4. The ratio of the households' dept to GDP in Turkey between 2005-20I6.

Source: The Bank for International Settlements, "BIS Quarterly Review"

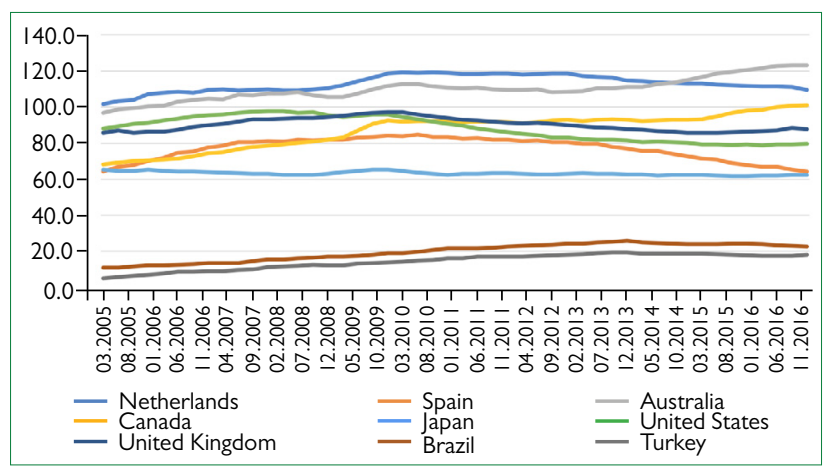

Figure 5. The ratio of households debt to GDP.

Source: The Bank for International Settlements, "BIS Quarterly Review" 
tion density with 2.821 people per $\mathrm{km}^{2}$ in Turkey. According to the BRSA data, Istanbul has $54.3 \%$ of the bank deposits and $40.72 \%$ of the total loans used in Turkey, so almost half of the financial transactions of the country occur in Istanbul. As of $2015,53.5 \%$ of Turkey's total exports and $56.8 \%$ of its imports are made in Istanbul. In the same year, the government made the largest public investment in the city with the percentage of $10.3 \%$ (The Union of Chambers and Commodity Exchanges of Turkey, 2015).

According to the data of the Turkish Statistical Institute, $17.3 \%$ of the homes sold in Turkey in 2016 , and $19.4 \%$ of the homes sold by mortgage loans in the same year are realized in Istanbul. It is the most preferred settlement area in Turkey for residential sales with or without using mortgage loans. With regard to the Central Bank of the Republic of Turkey's hedonic housing price index from January $201 \mathrm{I}^{13}$ istanbul has a higher value than other residential areas.

Within the scope of the study, when examining the mortgage loans given to the city of Istanbul in the period between 2010 and 2014 by the bank which is one of the biggest 5 banks of the housing loan market of the country, it is found that the average monthly income of those who use mortgage loans in Istanbul is approximately 6.3 times of the minimum wage. According to the same data, the average income of those whose education level is below university is 5.1 times of the minimum wage; the average income of the university graduates is 8.4, and the average income of those who have master or $\mathrm{PhD}$ degree is $1 \mathrm{I} .7$ times of the minimum wage. This situation reveals the simple fact that it is necessary to be a member of the middle class at least in order to use a mortgage loan in Turkey. There are serious obstacles to lower income groups in reaching the mortgage loan market. However, as shown in figure 4, the household debt is rising and this does not solely stem from the mortgage loans. According to the data from

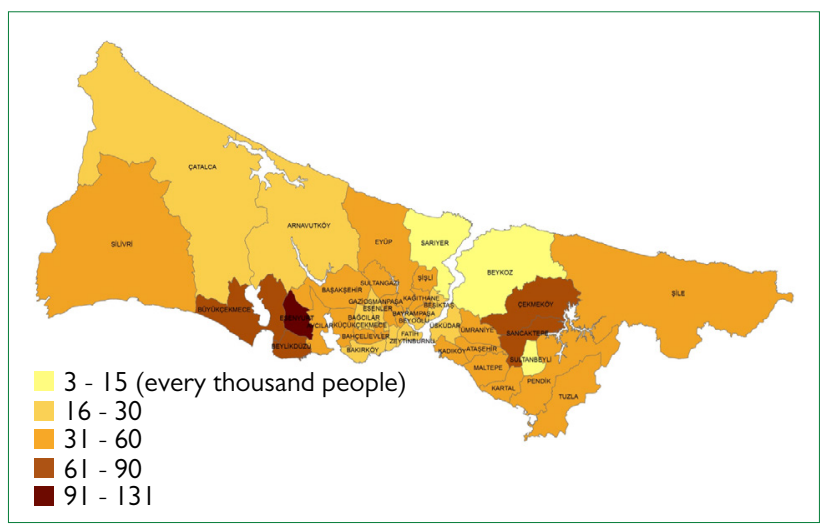

Figure 6. The Ratio of Mortgage Loans Used in Istabul to the District Population in the period between 2010 and 2016. Source: TSI.
June 2017 of the Banks Association of Turkey, $49.5 \%$ of the household loans are mortgage loans. Therefore, the access to loans constituting the remaining $50.5 \%$ is easier than it is in the mortgage market. Thus, they are used as different instruments in the spread of financialization.

As mentioned above, the real estate certificate system has entered into force. The real estate certificate was issued for the project known as "Park Mavera III" which was carried out in the had, which is a public institution and the biggest player in the Turkey's construction sector, and these certificates started to be traded on the stock exchange on 29 March 2017. However, the issued certificates lost about $21 \%$ in the course of a 6 month-period. In the interviews conducted within the scope of this study, a senior executive of the HAD stated that the certification system could not be explained to the public well-enough, while a mid-level executive of the Real Estate Investment Company, an organization of the HDA, stated that the scheduling and the exit price were inaccurate. Regardless of the performance of the certificate, its presence indicates that the urban area is being included in the new financial system. The interviewees were also asked about the period when the securitization process will go into operation. The representative of one of the 5 largest private banks stated that they have been working intensively for the issue and it is necessary to expect such an attempt from 2 or 3 banks within a few years, but it is early to say something about the amount of the demand.

Both the mortgage loan usage data and the population data gained from the TSI regarding Istanbul are evaluated together, and the ratio of the mortgage loans used in Istanbul in the period between 2010 and 2016 to the district population is seen in the figure 6 prepared by using the ArcGIS programme. While the data are sorted by the number of mortgage loans per thousand people, the color scale changes from open to

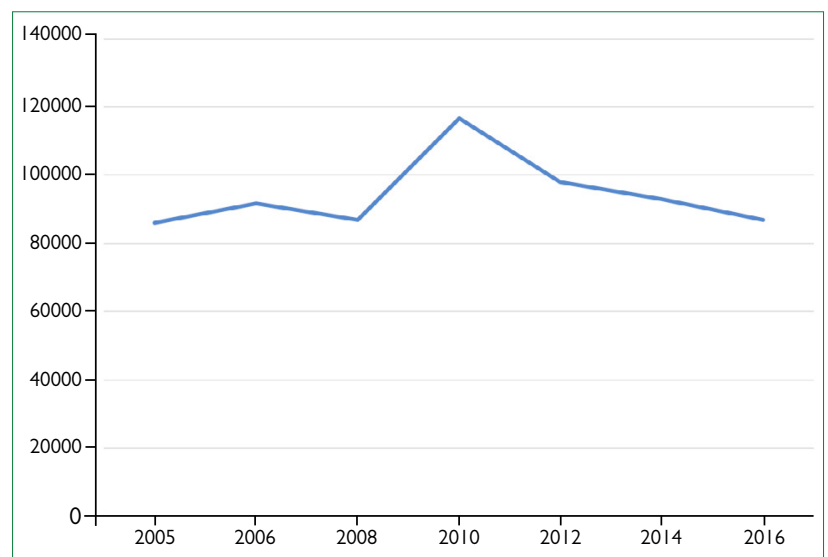

Figure 7. The Annual Numbers of Mortgage Loans Used in Istanbul. Source: TSI.

\footnotetext{
${ }^{13} \mathrm{http}: / /$ www.tcmb.gov.tr/wps/wcm/connect/tcmb+tr/tcmb+tr/main+menu/istatistikler/reel+sektor+istatistikleri/konut+fiyat+endeksi/veri+\%28tablolar\%29
} 
dark as the number of people who used mortgage loans increases. When the data set is examined, almost 13 out of every thousand citizens living in the district of Esenyurt have used mortgage loans. Esenyurt is followed by Beylikdüzü, Çekmeköy, and Büyükçekmece Districts, respectively. The main characteristic of these four districts is that they are hosting newly-emerging residential areas. All bankers, real estate development specialists, and real estate appraisers stated in the interviews conducted within the scope of this study that the use of mortgage loans in these districts is intensive because of investment purposes. It cannot be said that all mortgage loans used in these areas are taken only by those living in these areas. It can be seen on the Map that the two districts with the least use of mortgage loans according to the population are the districts of Beykoz and Sultanbeyli, and the districts of Sarıyer and Çatalca. Arnavutköy is also in the same range as Sarıyer and Çatalca. While 4.98 of every thousand people in Sultanbeyli used mortgage loans, this value is 3,28 in Beykoz. Işık and Pınarcıoğlu (200I) stated that the cyclical process of Sultanbeyli was based on the occupation of land. It can be said that the Sultanbeyli district is behind the other districts in terms of ownership of the building use permit, which is a condition for the suitability of the mortgage loan use. When the land uses of Beykoz, Sarıyer, Arnavutköy, and Çatalca districts in which the minimum number of mortgage loans used per capita are examined, it is seen that the forest area is located to the north of all these four districts. This forest area continues on the north of the entire city and is known as the North Forests. The mortgage loan performance of these four districts is similar, and the northern forests, most of which are hosted by these districts, constitute an important natural area that should be briefly addressed, although it is not the subject of this study. The "mega" projects of the local and regional governments continued with great aggression in the northern forests. These include the construction of the 3rd Bosphorus bridge, which is completed and opened for use, and also the construction of the 3rd Airport Project, which is still ongoing. Despite the fact that no mortgage loans can be used in the North Forests Region, the ruling elites have realized major projects on these areas. As a result of this policy, constructions have began on this area and it is expected that even larger fields will be opened to construction. Thus, to say that mortgage loans will not be used in the new housing projects that are to be built in this area will be contrary to the policies of the government and contrary to the natural flow of life as well.

Figure 7 shows the annual numbers of mortgage loans used in Istanbul in terms of the data taken from the Turkisk Statistical Institute (TSI). According to this chart, there is a decrease in the total mortgage loan usage after 2013, and this trend continues in the following years. Therefore, when conducting a survey on the use of mortgage loans proportionate to the population, it is thought that it would be more meaningful to

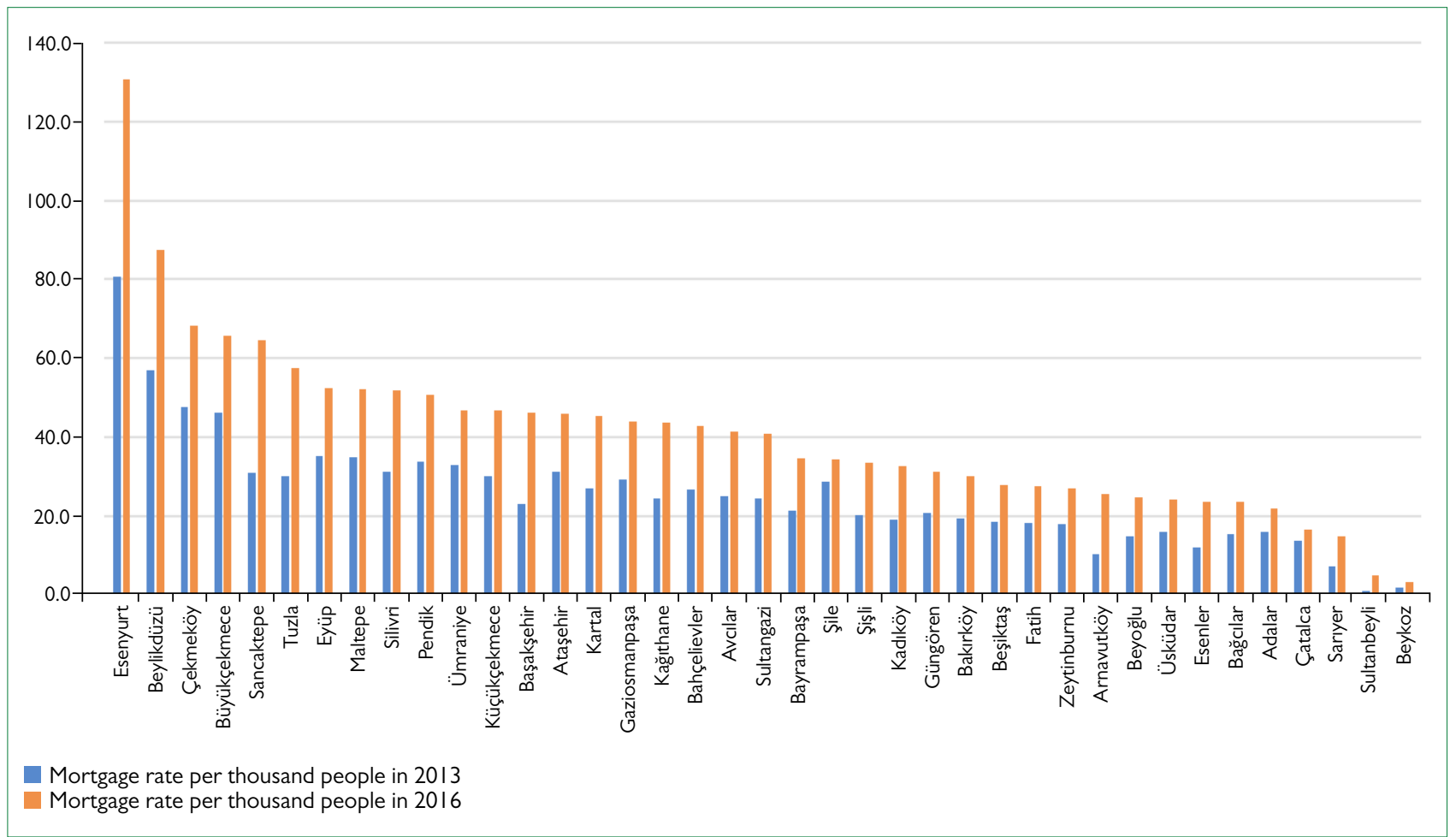

Figure 8. TThe comparison of the ratio of the total numbers of mortgage loans used in Istanbul in the period between 2010 and 2013 and the period between 2010 and 2016 to the population. 
compare the years 2013 and 2016, and figure 8 is prepared in this direction. Accordingly, the ratio of the mortgage loans used to the population does not tend to decrease, but it increases. This is because Istanbul's population growth rate is lower than the increase rate in the number of mortgage loans used. Nevertheless, it is possible to say that there has been a steady decline in the use of mortgage loans after 2013.14

\section{Conclusion}

This study examined the financial transformation process of Turkey since the crisis in 200I. Household loans, household debt obligations, the legislation that was issued, and the practices were examined and an attempt was made to find out if there was any financialization within this transformation process.

After the 200I economic crisis in Turkey, the credit debt of households reached an unparallelled size due to the new economic management strategies. Mortgage loans began to be used and in the short-term they had a rate approaching $40 \%$ of housing purchases. The legislative infrastructure was set up to enter the secondary markets, and private banks continue trying to enter the system, albeit with reservations. Istanbul, Turkey's most prominent city in many respects, is also leading the way in the use of mortgage loans. While Turkey's financialization process continues, it will not be misleading to expect that this period will soon be accelerated by the introduction of the derivative markets that will be developed due to mortgage. This will show itself as a much more rapid acceleration of the strong tendency of the exchange value taking the place of the use value in the spatial plane.

It is seen in Map I that the rate of mortgage loans use is higher in the newly developed urban areas compared to the traditional residential areas in Istanbul. In addition, new development areas in Istanbul are being organized under the guidance of mega projects. Along with the completion of these mega projects, it is not wrong to expect that the use of mortgage loans will reach high values for Turkey in the forest areas, where these mega projects are carried out.

During the financialization process in Turkey, the state plays an active role by regulating the legal system and developing strategies to increase financial literacy. The practices implemented by the state have effects on everyday life. The households' indebtness is accelerated by the spread of mortgage loans as well. It is understood that mortgage loans, which are seen as a solution to the problem of housing in the middle class in Turkey, are one of the main factors that provide financialization.
In a late capitalist country such as Turkey, whose mortgage market volume is not so big, one of the main questions to be answered is whether the financialization process can continue or not. It also needs to be investigated whether the household debt, which has increased more than triplicate in II years, will cause a new economic crisis. It can also be argued that the difference between the mortgage use rates in the new development areas, where the rates are higher, and the old city center will lead to the renewal of the old urban fabric in Istanbul.

\footnotetext{
${ }^{14}$ When the data were taken from the Turkish Statistical Institute, no data regarding Adalar (Prince Islands), Çatalca, and Şile for the 2015 and 2016 were given. While the population of Adalar (Prince Islands) decreased from 2014 to 2016, the population growth rate of Çatalca was lower than that of Istanbul, while the population growth rate of Şile was higher than that of Istanbul in the same period. On the other hand, the color and numerical value to be displayed on the Map will be almost the same when the data of the 3 districts for the period between 2014 and 2016 is taken into account.
} 


\section{REFERENCES}

Aalbers, M. B. (2008). The Financialization Of Home And The Mortgage Market Crisis. Competition \& Change, 12.2 148-166.

Aalbers, M. B. (2016). The Financialization Of Housing: A Political Economy Approach. London \& New York: Routledge.

Aalbers, M. B. (2017). The Variegated Financialization Of Housing. International Journal Of Urban And Regional Research, 41.4 542-554

Akçay, Ümit (2009)“2001 Krizi Sonrası Yapısal Reformlar Bağlamında Kamu İdaresinin Yeniden Düzenlenmesi: Türkiyéde Merkez Bankası Bağımsızlığını Nasıl Anlamak Gerekir?", Der. Necati Akyıldız Vd. 18. Yüzyıldan 21. Yüzyıla Kamu Yönetiminde Reform, Ankara: TODAİE Yayınları, S. 251-264

Akçay, Ü., Güngen, A. R. (2016). Finansallaşma, Borç Krizi Ve Çöküş: Küresel Kapitalizmin Geleceği. Ankara: Notabene.

Arrighi, G. (1994). The Long Twentieth Century: Money, Power, And The Origins Of Our Times. London: Verso Books.

Balaban, O. (2007). Bir Konut Finansman Aracı Mortgage Sisteminin Türkiyéde Olası Etkileri Üzerine. Kent Ve Planlama. Ayşegül Mengi (Ed.) Geçmişi Korumak Geleceği Tasarlamak içinde (s. 237-258). Ankara: İmge.

BIS Quarterly Review, September 2016

Çelik, Ö., Karaçimen, E. (2017). Türkiye'de Gayrimenkul Ve Finansın Derinleșen Ve Yeniden Yapılanan İlişkisi. Pınar Bedirhanoğlu, Özlem Çelik, Hakan Mihcı. (Ed.) Finansallaşma Kıskacında Türkiyéde Devlet, Sermaye Birikimi Ve Emek içinde (s. 83-102). Ankara: Notabene.

Celik, O., Topal, A., \& Yalman, G. (2016). Finance And System Of Provision Of Housing. The Case Of Istanbul, Turkey (No. Wpaper152).

Dinçel, G. (2015). Büyüme Bağlamında İnşaat Sektörü. Türkiye Sınai Kalkınma Bankası Araştırma, Ekonomik Araştırmalar, İstanbul.

Dymski, G A. (2009). Racial Exclusion And The Political Economy Of The Subprime Crisis. Historical Materialism 17.2, 149-179.

Durand, C. (2017). Fictitious Capital: How Finance Is Appropriating Our Future. Londo: Verso Books.

EMF, HYPOSTAT 2017 A Review Of Europe's Mortgage And Housing Market https://hypo.org/app/uploads/sites/3/2017/09/ HYPOSTAT-2017.pdf

ERGÜDER, B. (2017). Türkiyéde İnşaat Sektöründe Büyüme Ve Menkulleștirme: Vergi Ve Yasal Düzenlemeler. Institutions, National Identity, Power, And Governance In The 21st Century, 191-208

Fainstein, S. (2016). Financialisation And Justice İn The City: A Commentary. Urban Studies 53.7, 1503-1508.

Fernandez, R., \& Aalbers, M. B. (2016). Financialization And Housing: Between Globalization And Varieties Of Capitalism. Competition \& Change, 20(2), 71-88.

Fields, D. (2015). Contesting The Financialization Of Urban Space: Community Organizations And The Struggle To Preserve Affordable Rental Housing İn New York City. Journal Of Urban Affairs 37.2, 144-165.

Gotham, K. F. (2009). Creating Liquidity Out Of Spatial Fixity: The Secondary Circuit Of Capital And The Subprime Mortgage Crisis. International Journal Of Urban And Regional Research 33.2, 355-371.

Güngen, A. R. (2017). Finansal Tabana Yayılma Siyaseti Ve Türkiyéde Devletin Finansallaşması. Pınar Bedirhanoğlu, Özlem Çelik, Hakan Mihcı. (Ed.) Finansallașma Kıskacında Türkiyéde Devlet, Sermaye Birikimi Ve Emek içinde (s. 23-44). Ankara: Notabene.

Güngen, A. R. (2017). Financial Inclusion And Policy-Making: Strategy, Campaigns And Microcredit A La Turca. New Political Economy, 1-17.

Haiven, M. (2014). Crises Of İmagination, Crises Of Power: Capitalism, Creativity And The Commons. London $\&$ New York: Zed Books Ltd.

Harvey, D., (1985). The Urbanization of Capital, Baltimore: Johns Hopkins University Press.

Işı1k, O, Pınarcıoğlu M. (2001). Nöbetleșe Yoksulluk Gecekondulaşma Ve Kent Yoksulları: Sultanbeyli Örneği. İstanbul: İletişim Yayınları.

İslamoğlu, H. (2002). Yeni Düzenlemeler Ve Ekonomi Politik: IMF Kaynaklı
Kurumsal Reformlar Ve Tütün Yasası. Birikim, 158, 20-27.

Karaçimen, E. (2015). Türkiyéde Finansallşama: Borç Kıskacında Emek. İstanbul: SAV Yayınlar1

Kömürlü, R., \& Önel, H. (2007). Türkiyéde Konut Üretimine Yönelik Kaynak Olușturma Model Yaklaşımları. Megaron 2.2., 89-107.

Krippner, G. R. (2005). The Financialization Of The American Economy. Socio-Economic Review, 3(2), 173-208.

Penpecioğlu, M. (2016). Kapitalist Kentleșme Dinamiklerinin Türkiyédeki Son 10 Yılı: Yapılı Çevre Üretimi, Devlet Ve Büyük Ölçekli Kentsel Projeler. Tanıl Bora (Ed.), İnşaat Ya Resulullah İçinde (163-180). İstanbul: Birikim Kitapları.

Pereira, A. L. D. S. (2017). Financialization Of Housing İn Brazil: New Frontiers. International Journal Of Urban And Regional Research, 41(4), 604-622.

Rolnik, R., (2013)."Late Neoliberalism: The Financialization of Homeownership and Housing Rights", International Journal of Urban and Regional Research, 37: 1058-1066.

The Union Of Chambers And Commodity Exchanges Of Turkey, 2015 Ekonomik Rapor https://www.tobb.org.tr/documents/yayinlar/2016/ 72gk/72-genel-kurulekonomikrapor2015.pdf

Topbaş, K. (2008, 17 Ağustos). Deprem konusunda yitirecek 1 dakikamız yok http://www.hurriyet.com.tr/topbas-deprem-konusunda-yitirecek-1dakikamiz-yok-9683293

van Loon, J., And Manuel B. A. (2017) How Real Estate Became Just Another Asset Class': The Financialization Of The İnvestment Strategies Of Dutch İnstitutional İnvestors. European Planning Studies 25.2, 221-240.

\section{INTERNET REFERENCES}

https://www.teb.com.tr/finansal-okuryazarlik-nedir/

http://www.tcmb.gov.tr/wps/wcm/connect/feb004f0-bb3c-4d52-bbff086c0c72c072/eylemplani.pdf?MOD =AJPERES $\&$ CACHEID $=$ ROO TWORKSPACE-feb004f0-bb3c-4d52-bbff-086c0c72c072-kCzrKGg 